\title{
Self-Esteem and Life Satisfaction in University Students: a Study Report
}

\section{Zülbiye Kaçay ${ }^{*}$, Selman Çutuk², Vahit Çiris3, ZeynepAkkus Çutuk4}

'Çanakkale Onsekiz Mart University, Faculty of Sports Sciences, Çanakkale, Turkey

${ }^{2}$ Nisantasi University, Sports Management Deparment, Istanbul, Turkey

${ }^{3}$ Kırsehir Ahi Evran University, Faculty of Sports Sciences, Kirsehir, Turkey

${ }^{4}$ Trakya University, Department of Educational Sciences, Edirne, Turkey

Study Area: Istabul, Turkey

Coordinates: $41^{\circ} 00^{\prime} 49$ ? N; $28^{\circ} 57^{\prime} 18$ ?E

Introduction:

The university period can be expressed as a process in which individuals experience changes and developments in many ways, their perspectives towards life are shaped, perhaps for the first time, they stay away from the family and the environment they grew up in, and learn to stand on their own feet (Kaçay et al., 2017). Therefore, emotional changes experienced by individuals during this period, adaptation to the new social environment, and the feeling of loneliness in this process can affect their self-esteem and life satisfaction levels positively or negatively depending on how they go through this process.

Self-esteem is generally defined as the judgment that an individual makes about himself as a result of evaluating himself with a critical point of view (Leary \& Baumeister, 2000; Cobb, 2003; Zywica \& Danowski, 2008; Havi \& Samaha, 2017). The Judgment, which is the result of the balance between the current situation and the desired state, expresses self-esteem.

Individuals with high self-esteem are independent and show positive behavioral characteristics such as leadership skills, resilience to stress (Batsiou et al., 2020), selfconfidence, feeling valued, assertiveness, resilience (Khezerlou, 2017), self-confidence, self-esteem (Salmivalli et al., 2020). The qualities or values that constitute the essence of the individual are not innate. Humans are born with visible physical features and undiscovered qualities. On the other hand, their ability to judge themselves with certain attributes develops as a result of their interaction with norms such as family, environment, education, culture,

\section{Abstract}

A total of 361 students, 221 females and 140 males, participated in the study designed by using relational screening model. Self-Esteem Scale, Life Satisfaction Scale and Personal Information Form were used in the study. There was no signif icant difference between life satisfaction and self-esteem in terms of gender and faculty was evidenced, but there was a positive and significant relationship between age and class level found. It was determined that there is a significant and positive relationship between life satisfaction and self-esteem. The results were discussed in accordance with the relevant literature.

Key words: Personality, Sport Education, E-learning

and society. In this context, if the individual describes and appreciates himself as valuable and happy in line with his goals, high self-esteem can be mentioned (Kaçay et al., 2017). It is emphasized that individuals with high self-esteem and self-awareness are more moderate, have strong communication, have sound psychology, are open to learning and teaching, are hardworking, are more willing to achieve their goals, and have higher life satisfaction (Sever et al., 1993). Chen et al., (2006); Diener \& Diener (1995); Ye et al., (2012) generally associated self-esteem with high life satisfaction. Butkovic et al., (2020) conceptualized selfesteem as a predictor of life satisfaction. According to the definition of Abu Jado, (2015) self-esteem, which is expressed as self-assessment of the individual's mental, physical, social, and moral characteristics, is one of the main factors that will contribute to the individual's positive or negative self-awareness.

Life satisfaction is the cognitive assessment of an individual's quality of life as a part of subjective well-being (Diener, 1984). In otherwords, life satisfaction is a term used to express the general well-being and quality of life of the individual (Veenhoven, 1996) and may be affected by factors such as age, gender, socio-economic status, the environment, and the individual's self-esteem (Koker, 1991). In this context, life satisfaction can be expressed as the feeling of satisfaction that occurs as a result of an individual's self-assessment of his life. On the other hand, life satisfaction may vary depending on the size of the difference between what an individual has and what he or she wants to have. Therefore, as stated by Elliott \& Shin

*Corresponding Author: zzkacay@gmail.com 
(2002), the Life satisfaction of university students can be directly proportional to how much their expectations from the university are met.

This study aimed to determine the relationship between self-esteem and life satisfaction of university students, who would form the future of society. It is thought that the suggestions to be presented based on the findings of the study will shed light on individuals to continue their careers and lives on a more solid basis and will contribute to the literature in this field.

\section{Materials and Methods:}

This research was conducted on a total of 361 students, 221 $(61.21 \%)$ female and $140(38.78 \%)$ male, studying at the Faculty of Education and the Faculty of Sport Sciences and selected through random sampling. Students were between the ages of 18-40 and their average age was 21.64 (Sd: 3.39). The number of students studying at the faculty of education was $187(51.8 \%)$ and the number of students studying at the faculty of sports sciences was 174 (48.2\%). Considering the distribution of the sample according to the grades, 113 (31.3\%) were 1st-year students, 99 (27.4\%) 2ndyear students, $40(11.1 \%)$ 3rd-year students, and 109 (30.2\%) 4 th-year students.

In the study, the Self-Esteem Scale, Life Satisfaction Scale, and Personal Information Form prepared by the researcher were used.

Life Satisfaction Scale- The scale is a 7-point fiveitem measurement tool developed by Diener et al., (1985). In the original form of the scale, the internal consistency reliability coefficient was .87 , and the criterion-dependent validity was .82 . The scale was adapted to Turkish by Köker (1991) and Yetim (1991). Yetim (1991) found the internal consistency reliability coefficient of .86 in the Turkish form; test-retest reliability coefficient .73; Köker (1991) found that the test-retest reliability coefficient as .85 ; the internal consistency coefficient ranged from .81 to .86 for all age groups. As a result of the analyzes conducted within the scope of this research, the Cronbach alpha internal consistency reliability coefficient of the scale was calculated as .83 .

Rosenberg Self-Esteem Scale (RSES)- The scale was developed by Rosenberg (1965). RSES consists of 12 subscales and a total of 63 questions. The first subdimension of RSES is self-esteem and the first 10 items measure this sub-dimension. In this study, the first to items of the scale were used to measure students' self-esteem levels. In the original form of the scale, the test-retest reliability coefficient was found to vary between $.82-.88$ and Cronbach alpha internal consistency reliability coeff icient ranged between $.77-.88$. The scale was adapted to Turkish by Çuhadaroglu (1986). In the reliability study conducted for the Turkish form of the scale, it was determined that the test-retest reliability coefficient was ranged from .48 to .79. In this study, the Cronbach alpha internal consistency coefficient of the self-esteem subdimension was 85 .

Personal Information Form- The form prepared by the researcher comprised of four questions regarding the participants' gender, age, faculty, and class level.

The data obtained in the research were analyzed by using SPSS 22.00 for the Windows package program. Whether the variables show a normal distribution or not was determined according to the Kurtosis and Skewness values. Accordingly, the skewness value of the self-esteem variable was determined as -.71 and the kurtosis value as .41; It was determined that the skewness value of the life satisfaction variable was -.22 and the kurtosis value was -.32 . Huck (2012) stated that kurtosis and skewness values should be less than \pm 1 in a normal distribution, George \& Mallery (2010) stated that the \pm 1 value for skewness and kurtosis is perfect, but \pm 2 value is acceptable for some psychometric measurements. Accordingly, the values obtained show that there was no significant problem in the normal distribution for both variables. Then, the t-test for paired comparisons and Pearson Correlation Coefficient were used to determine the direction and level of the relationship. $a=0.05$ was chosen for the level of signif icance.

\section{Results:}

Table-1: T-Test Results of Scores Obtained from Self-Esteem Scale by Gender

\begin{tabular}{lllllll}
\hline Gender & $\mathrm{N}$ & $\mathrm{X}$ & $\mathrm{S}$ & $\mathrm{Sd}$ & $\mathrm{T}$ & $\mathrm{P}$ \\
\hline Female & 221 & 21.40 & 5.65 & 359 & -.870 & .385 \\
Male & 140 & 21.95 & 5.96 & & & \\
\hline
\end{tabular}

As seen in Table 1, the scores obtained from the selfesteem scale do not show a signif icant difference according to gender $(\mathrm{t}(359)=-.870, \mathrm{p}>.05)$.

Table-2: T-Test Results of Scores Obtained from Life Satisfaction Scale by Gender

\begin{tabular}{lllllll}
\hline Gender & $\mathrm{N}$ & $\mathrm{X}$ & $\mathrm{S}$ & $\mathrm{Sd}$ & $\mathrm{T}$ & $\mathrm{P}$ \\
\hline Female & $\mathbf{2 2 1}$ & $\mathbf{2 1 . 2 7}$ & $\mathbf{6 . 1 3}$ & 359 & $\mathbf{- 1 . 1 5 4}$ & .249 \\
Male & $\mathbf{1 4 0}$ & $\mathbf{2 2 . 1 1}$ & $\mathbf{7 . 5 7}$ & & & \\
\hline
\end{tabular}

According to Table 2, the scores obtained from the life satisfaction scale do not show a significant difference according to gender $(\mathrm{t}(359)=-1.154, \mathrm{p}>.05)$.

Table-3.T-Test Results of Scores Obtained from Self-Esteem Scale According to Faculty Variable

\begin{tabular}{lllllll}
\hline Faculty & $\mathrm{N}$ & $\mathrm{X}$ & $\mathrm{S}$ & $\mathrm{Sd}$ & $\mathrm{T}$ & $\mathrm{P}$ \\
\hline Education & 187 & $\mathbf{2 1 . 3 4}$ & 6.40 & 359 & $\mathbf{- . 9 2 2}$ & .357 \\
SportSciences & 174 & $\mathbf{2 1 . 9 0}$ & 5 & & & \\
\hline
\end{tabular}

Table-4: T-Test Results of the Scores Obtained from the Life Satisfaction Scale, According to the Faculty

\begin{tabular}{lllllll}
\hline Faculty & $\mathrm{N}$ & $\mathrm{X}$ & $\mathrm{S}$ & $\mathrm{Sd}$ & $\mathrm{T}$ & $\mathrm{P}$ \\
\hline Education & $\mathbf{1 8 7}$ & $\mathbf{2 2 . 1 0}$ & $\mathbf{8 . 3 4}$ & $\mathbf{3 5 9}$ & $\mathbf{1 . 4 8 3}$ & $\mathbf{. 1 3 9}$
\end{tabular}

SportSciences $\quad 174 \quad 21.05 \quad 4.33$ 
It was determined that the scores obtained from the self-esteem scale did not show a significant difference as per the faculty variable ( $t$ (359)=-.922, $\mathrm{p}>.05)$.

As seen in Table 4, the scores obtained from the life satisfaction scale do not show a significant difference according to the faculty $(\mathrm{t}(359)=-1.483, \mathrm{p}>.05)$.

Table-5: The Relationship between Scores Obtained from various parameters

Self-Esteem Scale \& Age* (A signif icant and positive relationship) $\begin{array}{llllll}\text { Correlation }(\mathrm{r}) & .128^{* *} & \text { Significance (p) } & .015 & \text { N } & 361\end{array}$

Life Satisfaction Scale Scores and Age* (A significant and positive relationship)

Correlation (r) $\quad .233^{* *} \quad$ Significance (p) $\quad .013 \quad$ N 361

Scores of Self-Esteem Scale and Grade Level * (A significant and positive relationship)

Correlation (r) $\quad .194^{* *} \quad$ Significance (p) $\quad .000 \quad$ N 361

Scores Obtained from Life Satisfaction Scale and Grade Level * (A signif icant and positive relationship)

Correlation (r) $\quad .110^{*} \quad$ Significance (p) $\quad .036 \quad$ N 361

Self-Esteem and Life Satisfaction *** (A significant and positive relationship )

Correlation $(\mathrm{r}) \quad .444^{* *}$ Significance $\quad .000 \quad \mathrm{~N} \quad 361$

*Pearson Moments Product Correlation Coeff icient

**Spearman Brown Rank Difference Correlation Coefficient

\section{Discussion:}

In this study, it was determined that there was no significant difference between self-esteem and life satisfaction, gender, and faculty, and there was a positive and significant relationship between age and class level. A significant and positive relationship was found between self-esteem and life satisfaction.

In the related literature, similar to our study, besides the studies stating that life satisfaction, emotional selfefficacy has no relation with gender; there are also studies indicating that there is such a relationship different from our research.

In this study, it was concluded that there was no significant difference between self-esteem and gender and faculty. When the literature was examined, it was seen that there were studies supporting this result, and studies contradicting this result. Baybek \& Yavuz (2005) and Karademir et al., (2010), found that self-esteem levels were observed at similar rates in both genders and there was no statistically significant difference between them. Akça (2012), Dinç (1992), and Hatipoğlu (1996) concluded in their research that male adolescents' self-esteem scores were higher than female adolescents. Quatman \& Watson (2001) concluded in their study that boys' self-esteem scores were higher than girl's.

Another result obtained was that there was no significant difference between life satisfaction and gender and faculty. Kirişoğlu (2016) concluded in his study that there is no significant relationship between life satisfaction and gender. Contrary to this study, Dost (2007) found that life satisfaction of women was higher than men in his study on university students. There was no study in the literature investigating the relationship between self-esteem and life satisfaction and faculty.

In this study, it was determined that there was a positive and significant relationship between self-esteem and age and grade level. Gür (1996) and Karademir et al., (2010) found that as age increases, self-esteem increases. This finding supports the research. On the other hand, in the studies of Yüksekkaya (1995), Durak (1997), and Kirişoğlu (2016), no significant difference was found between the age variable and self-esteem. When examined in terms of class level, it was seen that as the class progressed, the self-esteem of individuals increased (Karadağ et al., 2008). Altık et al., (2010), in their study, found higher self-esteem scores of senior students than those studying in the first year.

Another result of the study was that there was a positive and significant relationship between life satisfaction and age and grade level. Kirişoğlu (2016) concluded in his study that there was no significant relationship between life satisfaction and age.

In this study, it was determined that there was a significant and positive relationship between self-esteem and life satisfaction. Kirişoğlu (2016), Cattık \& Aksoy (2018) found a strong relationship between self-esteem and life satisfaction. In many studies, a positive relationship between self-esteem and life satisfaction has been detected (Lucas et al., 1996; Yetim, 2002; Deniz, 2006; Chen et al., 2006; Çeçen, 2008; Uzman \& Maya, 2019). Aktaç \& Çetinkaya (2019) found a positive statistically significant relationship between self-esteem and life satisfaction in their study, in which they examined the relationship between professional self-esteem and life satisfaction of pre-service science teachers. Kaçay et al., (2017) state that sports and recreational activities increase life satisfaction by contributing to both the health and psychological wellbeing of the individual. In addition, as a result of their study on sports sciences faculty students, they found a strong positive relationship between resilience level and life satisfaction, no significant relationship was found in life satisfaction levels by gender, but when evaluated in terms of participation in sports, it was found that the life satisfaction of those who participated in sports activities was higher.

In line with the findings obtained in this study, it was considered that it would be beneficial to implement activities that improve self-esteem and life satisfaction in counseling practices or lesson programs starting from primaryeducation.

The study has some limitations. First, this research was conducted in two faculties. By conducting similar studies in more than one faculty, the results can be 
compared. It is considered that the findings of these studies are important in terms of generalizability. Another limitation is that the data obtained from the participants were obtained by self-reporting data collection tools. Therefore, the difficulties of self-reported measures should not be overlooked in the interpretation of the findings.

\section{References:}

Abu Jado, S.M. (2015): The psychology of social upbringing. Pub. by: Dar Al-Masirah, Amman Jordan.

Akça, Z.K. (2012): The relationship between perceived parental attitude and psychological resilience and selfesteem in young adulthood. Master's Dissertation, Maltepe University, Turkey.

Aktaç, V. \& Çetinkaya, M. (2019): Investigation of science teacher candidates' professional self-esteem and life satisfaction. L. Comp. Edu. Res., 7(14):575-599.

Altiok, H., Ek, N. \& Koruklu, N. (2010): Investigating the variables that related with self-esteem of the university students. Adnan Menderes Uni. Fac. Edu. J. Edu. Sci., 1(1):99-120.

Batsiou, S., Bournoudi, S., Antoniou, P. \& Tokmakidis, S.P. (2020): Self-Perception self-esteem physical activity and sedentary behavior of primary Greek-School students: A pilot study. Int. J. Instruc., 13(1):267-278.

Baybek, H. \& Yavuz, S. (2005): The Determination of Self Esteem in the Students of Mugla University. Mugla Üniversitesi Sosyal Bilimler Enstitüsü Dergisi, (14):73-95.

Butkovic, A., Tomas, J., Spanic, A.M., Hlupic, T.V. \& Bratko, D. (2020): Emerging adults versus middle-aged adults: Do they differ in psychological needs, self-esteem and life satisfaction. J. Happiness Stud., 21:779-798.

Chen, S.X., Cheung, F.M., Bond, M.H. \& Leung, J.P. (2006): Going beyond self-esteem to predict life satisfaction: The Chinese case. Asian J. Soc. Psychol., 9:24-35.

Cobb, R.J. (2003): The relationship between self-regulated learning behaviors and academic performance in webbased courses. Doctoral Dissertation, Virginia Polytechnic Institute and State University, ABD.

Çeçen, A.R. (2008): Sense of coherence, family sense of coherence and self-esteem in predicting life satisfaction among university students. J. Theory Pract. Edu., 4(1):19-30.

Çuhadaroglu, F. (1986): Self-Esteem in Adolescents. Psychiatry Dissertation, Hacettepe University, Turkey.

Deniz, M.E. (2006): The relationships among coping with stress, life satisfaction, decision making styles and decision selfesteem: An investigation with Turkish University Students. Soc. Behav. Person., 34(9):1161-1170.

Diener, E., Emmons, R.A., Larsen, R.J. \& Griffin, S. (1985): The satisfaction with life scale. J. Person. Asses., 49(1):71-75.

Dinç, F. (1992): The Effect of Self-Perception Levels of High School Students of Different Gender on Self-Esteem Levels. Master's Dissertation, Hacettepe University, Turkey.

Diener, E. (1984): Subjective well-being. Psychol. Bull., 95(3):542575 .

Diener, E. \& Diener, M. (1995): Cross-cultural correlates of lifesatisfaction and self-esteem. L. Personal. Soc. Psychol.,
68:653-663.

Durak, H. (1997): The Relationship Between the Self-Esteem Levels of Ankara Vocational School Students and Locus of Control. Master's Dissertation, Gazi University, Turkey.

Dost, M.T. (2007): Analysis of University Students' Life Satisfaction According to Some Variables. Pamukkale Univers. Fac. Edu., 2:132-143.

Elliott, K.M. \& Shin, D. (2002): Student satisfaction: An alternative approach to assessing this important concept. J. High. Edu. Policy Manag., 24(2):197-209.

George, D. \& Mallery, M. (2010): SPSS for Windows Step by Step: A Simple Guide and Reference. 17.0 update (10a ed.), Pub. by: Boston- Pearson.

Gür, A. (1996): The Relationship between depression and selfesteem in adolescence. Master's Dissertation, Hacettepe University, Turkey.

Hatipoglu, Z. (1996): Examining the Relationship Between Adolescent Students' Self-Design Levels and Perceived Maternal Behaviors. Master's Dissertation, Marmara University, Turkey.

Havi, N.S. \& Samaha, M. (2017): The relations among social media addiction, self esteem and life satisfaction among university students. Soc. Sci. Comp. Rev., 35(5):576-586.

Huck, S.W. (2012): Reading statistics and research (6th ed). Pub. by: Boston- Pearson.

Kaçay, Z., Demirel, M., Demirel, D.H., Isik, U. \& Soyer, F. (2017): Investigation of life satisfaction and resilience levels of the students studying at the school of physical education and sports according to various variables. Acta Kinesiol., 1(11):8994.

Kaçay, Z., Soyer, F. \& Demirel, M. (2017): Investigation of the relationship between self-esteem and assertiveness levels of University students. ERPA Int. Cong. Edu. Budapest.

Karadag, G., Güner, I., Çuhadar, D. \& Uçan, Ö. (2008): Self esteem at the gaziantep university health school of nursing students. Firat Saglik Hizmetleri Dergisi, 3(7).

Karademir, T., Dösyilmaz, E., Çoban, B. \& Kafkas, M.E. (2010): The self-esteem and emotional intelligence of students who participate in special ability examinations in order to attend the department of physical education and sport. Kastamonu Univers. Fac. Edu., 18(2):653-674.

Khezerlou, E. (2017): Professional self-esteem as a predictor of teacher burnout across Iranian and Turkish EFL teachers. Iranian J. Lang. Teach. Res., 5(1):113-130.

Kirisoglu, S. (2016): Investigation of the relationship between family structure and self-esteem and life satisfaction of young adults. Master's Dissertation, Haliç University, Turkey.

Köker, S. (1991): Comparison of life satisfaction level of normal and problematic adolescents. Master's Dissertation, Ankara University, Turkey.

Lucas, R.E., Diener, E. \& Suh, E. (1996): Discriminant validity of well-being measures. J. Person. Soc. Psychol., 71:616-628.

Salmivalli, C., Kaukiainen, A., Kaistaniemi, L. \& Lagerspetz, K.M. (1999): Self-evaluated self-esteem, peer-evaluated selfesteem, and defensive egotism as predictors of adolescents' 


\section{ORIGINAL ARTICLE}

participation in bullying situations. Person. Soc. Psychol. Bull., 25(10):1268-1278 .

Quatman, T. \& Watson, C.M. (2001): Gender differences in adolescent self-esteem: An exploration of domains. J. Gen. Psychol., 161(1):93-117.

Uzman, E. \& Maya, I. (2019): Self-Leadership strategies as the predictor of self-esteem and life satisfaction in university students. Int. J. Prog. Edu., 15(2):78-90.

Veenhoven, R. (1996): Happy life-expectancy. Soc. Ind. Res., 39:158.

Ye, S., Yu, L. \& Li, K. (2012): A cross-lagged model of self-esteem and life satisfaction: Gender differences among Chinese university students. Person. Indiv. Diff., 52:546-551.

Yetim, Ü. (1991): Life satisfaction in terms of the organization and pattern of personal projects. Doctoral Dissertation,
Ambient Science, 2020: Vol. 07(Sp1); 139-143 DOI:10.21276/ambi.2020.07.sp1.oa16

Ege University, Turkey.

Yetim, U. (2002): The impacts of individualism/collectivism, selfesteem, and feeling of mastery on life satisfaction among the Turkish university students and academicians. Soc. Ind. Res., 61(3):297-317.

Yüksekkaya, S. (1995): An Investigation of Self-Esteem in University Students in Terms of Various Variables. Master's Dissertation, Ege University, Turkey.

Zywica, J. \& Danowski, J. (2008): The faces of facebookers: Investigating social enhancement social compensation hypothesis; Predicting Facebook TM and offline popularity from sociability and self-Esteem, and mapping the meanings of popularity with semantic networks. J. Comp.-Mediat Comm., 14:1-34

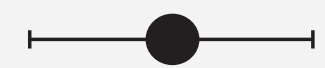

